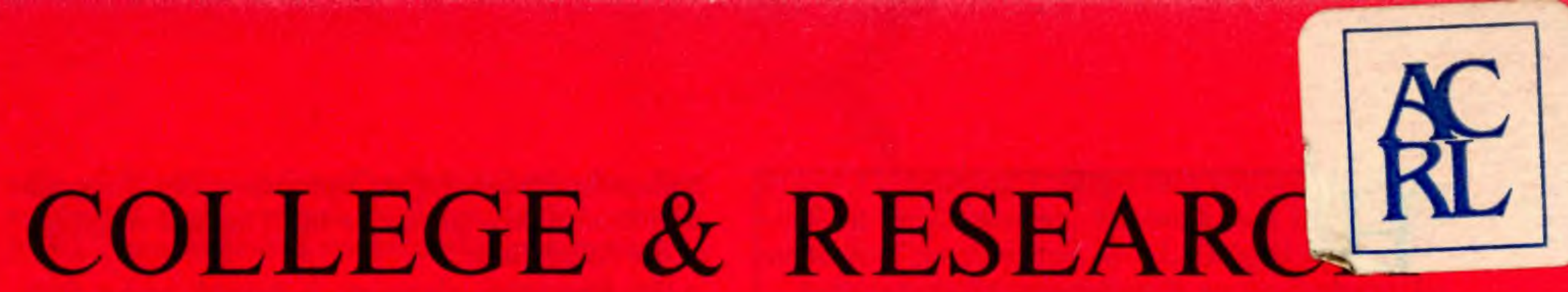
LIBRARIES

Association of College \& Research Libraries

\title{
July/August 1982
}

Vol. 43 , No. 7

\section{ACRL President's Report, 1981-82}

Since its founding in 1938, ACRL has been a major component of the American Library Association. Its current Statement of Responsibility makes the following commitment:

"The mission of ACRL is to represent academic and research librarians and libraries. This includes all types of academic libraries-community and junior colleges, college, and university - as well as comprehensive and specialized research libraries and their professional staffs. ACRL also has as its mission the enhancement of library service, in the broadest sense, to the academic and research communities."

There are many activities in pursuit of this mission, and The ALA Yearbook 1982 provides a summary on ACRL chapters, institutes and workshops, continuing education, publications, committee work, and the vari-

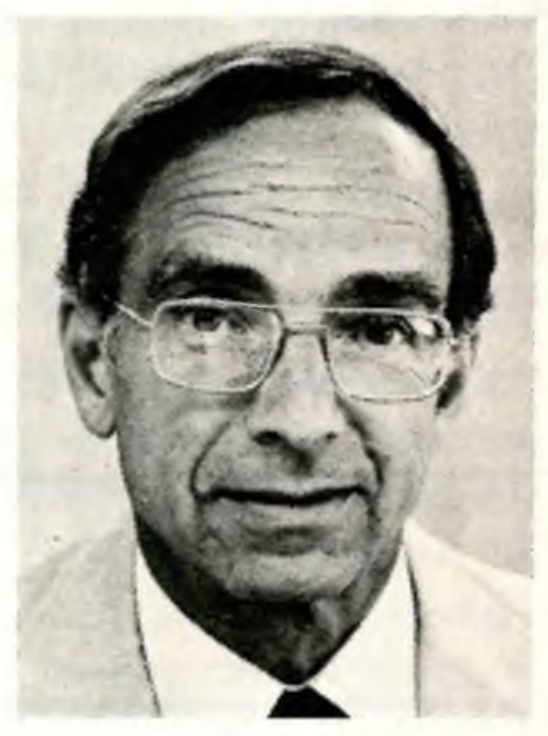

David C. Weber ACRL's $43 d$ President ety of ACRL section projects and programs.

This report will not repeat that information, but will provide current information on a few aspects. In an association of the size and vigor of ACRL, only the highlights can be provided here.

For any association sound planning is of primary, importance. This year a program activity model was developed for the coming decade. A committee chaired by David Kaser drafted this conceptual structure and a set of program activities designed to guide the Association toward the end of this decade. This model is designed to help shape the direction of efforts in the years immediately ahead, to raise thereby the sights of ACRL members and officers for achievement of the Association, and to stimulate membership interest and involvement in the advancement of the Association toward these goals. The report is in the May 1982 issue of C\&RL News and is a matter of ac- 
In this issue:

ACRL President's Report . . . 229

\section{A Conversation with}

Carla Stoffle

\section{Bibliographic Instruction: Extending Library Services to a Field-Based Program .}

News from the Field ......238

People ................240

Washington Hotline . . . . . . 2 245

New Technology . . . . . . . 247

Publications . . . . . . . . . 248

Calendar ...........250

Classified Advertising $\ldots . .251$ tion at the Philadelphia Conference. The program activities relate directly to the financial condition of the Association.

On financial planning I would make four points. First, expenditures including the Minneapolis Conference will this year be over $\$ 750,000$, in addition to which Choice magazine is a $\$ 900,000$ enterprise. As summarized in the December 1981 C $\&$ RL News, the budget is tight yet balanced. No new positions were funded. The Budget and Finance Committee believes the budget is prudent and the Board of Directors concurs.

Second, the dues increase was passed by vote last summer, making it the first increase in six years. It was an important step in assuring continued fiscal health; for without the increase support for 1982-83 programs would have had to be cut.

Third, there were in 1981-82 reserves of $\$ 30,000$ assigned for the first time, $5.8 \%$ of the base budget. This is regarded as an inadequate reserve considering income and expense shifts that could happen and must not be allowed to endanger the Association, especially since there is concern for the financial health of ALA as a whole.

Fourth, the "operating agreement" between ALA and its divisions has experienced many vicissitudes over the past two years. The current version of the agreement seems a reasonable compromise and should serve effectively as the necessary guide for the years immediately ahead.

In considering ACRL's finances as affected by ALA action, the Executive Committee in April gave special consideration to the current financial status of the ALA as it impacts ACRL staff and operational programs. The ACRL Executive Committee concluded that:

The first principle in responding to current budgetary conditions must be to maintain the quality of programs. This, in our judgment, requires a primary emphasis on the quality of ACRL staff, which in turn mandates competitive salaries and good benefits and other working conditions.

As a consequence, we urge there be no reduction in the benefit package, including vacations and insurance, as a means to resolve fiscal difficulties in any measure whatsoever. We support cost of living increases for 1982-83 to the extent feasible and have budgeted five per cent in order that ACRL could meet any ALA program to that extent. Merit increases are of extreme importance. Thus, we are preferring a reduction of staff rather than a weakening of the salary and benefit program in the conviction that the latter course will be much more harmful to ACRL and ALA in the years to come.

We urge the Executive Board to explore in depth the current ALA budgetary condition and to involve division officers and executive directors so that there can be a strong and informed consensus as to the best means for maintaining ALA strength. We are deeply concerned that the quality and the strength of ALA be maintained for the 
sake of libraries at large and specifically for the academic and research community for which ACRL has a particular responsibility of service."

There are a number of exceptional activities of the year that should also be mentioned. One is the exceedingly strong start to an ACRL program in continuing education that was provided by courses offered at the San Francisco Conference, and that were also provided at the Minneapolis Conference and are planned for the Philadelphia Conference. This is a response to needs of the ACRL members, and it is hoped that this will become an important self-financing part of ACRL activities. The second ACRL National Conference was held last October in Minneapolis with the theme "Options for the 80s." Designed by conference chair Virgil Massman and a strong committee, the Conference recognized this period of substantial and far-reaching change and took as its focus an assessment of the options that lie before us in this next critical decade.

Committee appointments this year resulted in $75 \%$ of the vacancies being given to members who were new appointees. And $44 \%$ of those whose names had been received by recommendation or by personal application were used on one or another committee. This included 24 individuals who were appointed as committee interns for a one-year period with the intent to provide some newer or younger members of ACRL with the experience of sharing in discussion, preparing working papers, contributing solutions, learning from the process, and demonstrating their capacities for further service to ACRL.

Given the long-standing major interest of ACRL in academic status and other personnel and career issues, a Study Group has been formed of members most of whom have recently served on ACRL committees or discussion groups concerned with one or another aspect of personnel management and career planning and staff development. Chaired by Page Ackerman, the Study Group will review the adequacy of Association activities and provide guidance for committee structure and charge or program activities that would provide a suitable and comprehensive coverage of these important matters. As a consequence ACRL may renew its effectiveness in this critical aspect of the profession.

Examples of committee work abound. A few products may be mentioned as indicative. $C \mho R L$ News has published revised "Guidelines for Two-Year College Resources Programs," "Guidelines for Extended Campus Library Services," "Guidelines for the Security of Rare Book, Manuscript, and Other Special Collections" in draft form, an "ACRL Legislative Policy and General Guide to Legislative Action," and an article by Meredith A. Butler as chair of the ACRL Ad Hoc Committee on Copyright treating the matter of "Copyright and Academic Library Photocopying," following which was a "Model
Policy Concerning College and University Photocopying for Classroom, Research and Library Reserve Use" as prepared by ALA's legal counsel.

A membership association is an opportunity for its members to achieve selected advances for the profession by a collective effort, as well as an opportunity for members to share experiences and learn from one another. I was impressed this year by the great number of academic and research librarians who have given so unstintingly of their time and thoughts. Individuals whom I have met at the three conferences provide me with great optimism about the future of our profession. I thank them all for their interest and their contributions. I am particularly grateful to Penny Abell for helping the Board of Directors with the important "operating agreement," Richard Talbot for exceptional leadership with his committee in the budgeting process, Keith Cottam and his committee for superior support in the appointments and nominations work, Richard Johnson for his willingness to serve the latter half of this year as acting editor and executive officer of Choice magazine, David Kaser for chairing the committee that developed the ACRL Activity Model, Jo Harrar as chair with respect to the "Research Agenda for the 80s," Evan Farber for his particularly wise counsel to ACRL in many ways, Carla Stoffle who has already shown that she will be an exceptional leader and fine ACRL president for 1982-83, and Deputy Executive Director Hal Espo who has made so many ACRL processes efficient and pleasant during his years at Headquarters from May 1978 to May 1982.

In her fifth year of service to this Association, I have been particularly impressed by the exceptional commitment and competence of Executive Director Julie Carroll Virgo. She has been wise, assertive, and judicious - even while pursuing a business management degree program at the University of Chicago, a commitment of time during 1981-83 that was understood and encouraged by ALA and by the ACRL Executive Committee. It is appropriate to conclude this report by quoting from the report of the Committee to Evaluate the Executive Director, chaired by Mary Frances Collins: "The response from the membership reflects a strongly positive assessment and endorsement of Ms. Virgo's performance as an Executive Director. The membership response indicates strong approval of her managerial and organizational skills and talent. She is perceived as being highly task-oriented, hard-working, efficient, and effective in her management of the Association."

Since an ACRL president is part-time and fleeting in his or her service, and committee members and section officers have rather little time to spare from their position of gainful employment, it is critical that the ACRL staff provide the continuity and dynamic full-time effort that helps a membership association succeed. I 
use this opportunity to thank the entire staff. And I recognize the five years of Julie Virgo's exceptional contributions and, on behalf of the membership, offer her our deep appreciation for her helping ACRL to be a major force in our profession.

David C. Weber President, ACRL

\section{A Conversation with Carla Stoffle}

Editor's Note: In June I had the opportunity to speak with Carla Stoffle, vice-president/ president-elect of ACRL, about the immediate future of ACRL and its activities.

Stoffle has been assistant chancellor for educational services at the University of Wisconsin-Parkside since 1978. She begins her term of office as 44th president of $A C R L$ at the end of the ALA annual conference in Philadelphia.

Ed.: What type of

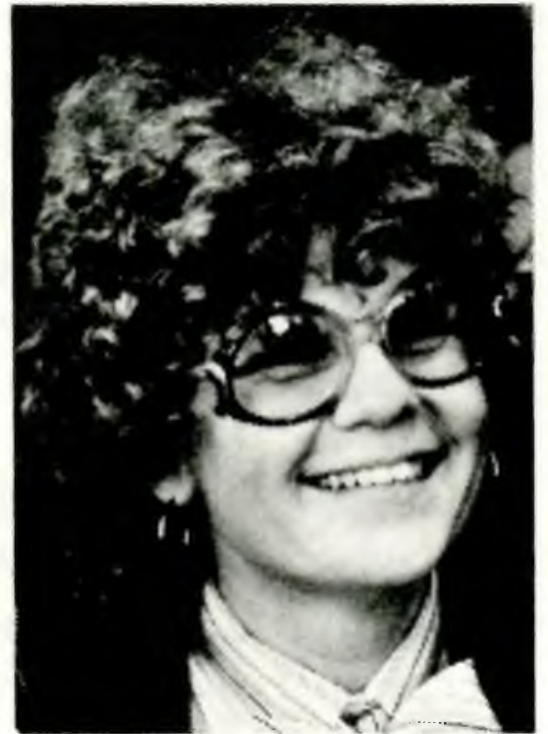

Carla Stoffle UW-Parkside areas of librarianship will you be emphasizing during your term as ACRL president?

Stoffle: I will be trying to encourage a response to the ACRL Activity Model for 1990. Much time and many resources were put into its development, and I hope that ACRL members will examine the proposal's recommendations closely. In order to ensure that ACRL remains a strong, viable organization in the future, the model's priorities will have to be continually examined. I would like to see the ACRL Planning Committee constantly identifying priorities and the ACRL Board using the Activity Model as a framework to judge the Association's activities.

Next year my presidential theme will be "Building Bridges." I would like to build bridges to other divisions and offices in ALA and improve the lines of communication with library schools. The Bibliographic Instruction Liaison Project will allow ACRL to build bridges with other professional associations, not only in terms of BI, but for the benefit of academic librarianship as a whole. I am also looking into a task force or discussion group on the role of academic libraries in higher education agencies and organizations.

Ed.: You have been a college administrator for four years now. From your perspective, what must academic librarians do to show administrators how vital their libraries are to higher education?

Stoffle: They need to take well-planned risks. I prefer an environment where people take the initiative and tell me as an administrator what direction they should be going in and how they should fit into the long-range goals of the institution. I think that librarians do not adequately communicate their victories and philosophies of librarianship to the senior administration. Nor do we communicate the potential the library has to assist many institutional programs. We should stimulate the faculty to examine their curriculum and teaching methods periodically simply by exposing them to library materials and services. Academic librarians can bring many research tools to their attention or enable them to shift their research focus by being involved in their subject areas and finding new information for them.

Very few libraries will be able to buy everything that someone on campus might want them to have. Collection development has become a major problem in the $80 \mathrm{~s}$-libraries not only must investigate resource-sharing, but they also need to offer alternative services to their parent institution to be active and effective on campus.

Ed.: Your publishing record and your association with the Bibliographic Instruction Section show you to be a most active proponent of BI. How does bibliographic instruction fit into ACRL's future?

Stoffle: Bibliographic instruction librarians are concerned about the educational mission of the academic library in the broad sense as well as in specific programs. BIS members may become more involved in ACRL or ALA-wide programs. ACRL has played a critical role in the growth of instruction programs and in the acceptance of instruction by the profession in the last 25 years. The Association has and will continue to recognize the importance of $\mathrm{BI}$, provide a framework for people with ideas who need to share those ideas with others, and provide training and legitimacy for user instruction professionals. 